ISSN 1676-3742

\title{
Identidade e missão do presbítero: perspectivas e desenvolvimento do Vaticano II
}

\author{
Identity and Mission of the Presbyterate: \\ Perspectives and Development of Vatican II
}

D. Filippo Santoro

\section{Resumo}

O artigo discorre sobre a identidade e missão do presbítero nas perspectivas do Vaticano II. Considera-se a origem do ministério na consagração e missão que Cristo comunica com o triplex munus, mostrando-se que aos bispos ficam unidos os presbíteros. Consideram-se fundamentos cristológicos, pneumatológicos e eclesiológicos. Mostra-se o caráter missionário de sua vocação, também educativo. Destaca-se a importância da sua espiritualidade.

Palavras-chave: Presbítero. Bispo. Missão. Espiritualidade. Pastoral.

\begin{abstract}
The article discourses about the identity and mission of the presbyterate, within the perspectives of Vatican II. It looks at the origin of the ministry in the consecration and mission which Christ communicates with the triplex munus, demonstrating that presbyters remain united to bishops. The article considers christological, pneumatological and ecclesiological bases. It shows the missionary, as well as the educational character of this vocation. It emphasizes the importance of its spirituality.
\end{abstract}


Keywords: Presbyterate. Bishop. Mission. Spirituality. Pastoral.

\section{Introdução}

A atualidade do tema a enfrentar não pode deixar de retomar algumas expressões que assumiram um valor determinante na compreensão mesma do ministério presbiteral no estilo de "Bergoglio", como já os jornalistas freqüentemente dizem. Expressões como "sejam pastores com cheiro das ovelhas" (Missa do crisma, 28 de março de 2013) - portanto, o sacerdote deve carregar consigo o odor das almas que pastoreia, não pode deixar de ser excelente hermeneuta conciliar a respeito do tema aqui tratado. O Papa Francisco naquela mesma circunstância indica o acréscimo de outra fragrância: óleo de Cristo, o Ungido de Deus vindo para derramar na humanidade, está sua substância divina. "Um bom sacerdote se reconhece como ele unge seu povo; isto - diz - é clara prova" do seu ser verdadeiro pastor. Além disso, "O sacerdote que sai pouco de si, que unge pouco (...) ao invés de ser mediador, torna-se pouco a pouco um intermediário, um gestor". Colhamos de repente dois critérios guias que podem introduzir-nos no tema do padre na sua missão: a relação íntima e fecunda com Cristo e sua missão em estreita sintonia com a Igreja, com os fiéis. Aspectos que recordam a história de tantos padres santos que em nossas Igrejas se desgastaram sem limites por esta nobilíssima causa, com generosidade heróica e dos quais também nós somos testemunhas e herdeiros.

No alvorecer do Concílio, o padre aparece primeiramente como "sacerdote", homem do sagrado, "cura", título com o qual se designava o pároco cura de almas, segundo a terminologia teológica e canônica pós-tridentina. O sacerdote, portanto, é uma figura-chave no cenário da vida do território onde a relação Igreja-sociedade era um fator ainda bastante forte. O concílio, porém, já discorre o deslocamento em ato entre sociedade e Igreja, como duas "irmãs" que antes tinham dividido a mesma casa e a mesma mesa e história e de repente tomaram caminhos diferentes, talvez também opostos. A releitura teológica do ministério ordenado permite retornar às raízes de uma história bimilenária e colher constantes fatores temporâneos valiosos.

\section{Os fundamentos do presbiterado no Vaticano II}

O concílio começou a aprofundar a teologia do presbiterado quando já tinha sido delineada com toda sua profundidade a teologia do episcopado no 
capitulo III da Lumen Gentium ( $L G)$. Este tratamento já no n. 28 apresenta a figura do presbítero, unido e dependente do bispo, por força do sacramento da ordem em uma dimensão ministerial e missionária, no horizonte do sacerdócio comum dos fiéis.

A origem do ministério está no mesmo Senhor que comunica sua "consagração" e sua "missão" aos apóstolos e através destes aos bispos que são os continuadores da sua missão pastoral. O ministério é um dom do alto que nasce de Cristo para o serviço da comunidade. A fonte da graça é Cristo que a transmite mediante os apóstolos e os bispos e através destes aos sacerdotes e aos diáconos.

Os presbíteros não possuem o ápice do supremo sacerdócio (pontificatus apicem), mas unidos ao bispo possuem a dignidade sacerdotal, são "verdadeiros sacerdotes do Novo Testamento". Estão a serviço de todo o povo de Deus. A segunda parte do texto conciliar, em LG 28b, descreve as relações entre sacerdotes e seu bispo "com o qual formam um único presbitério". "Reconheçam o bispo verdadeiramente como seu pai e reverentemente lhe obedeçam. O bispo, porém, considere os sacerdotes, seus cooperadores, como filhos e amigos", "unidos entre si por íntima fraternidade" para "servir ao bem de toda a Igreja".

Enfim os presbíteros "como pais em Cristo, cuidem dos fiéis que eles espiritualmente geram pelo Batismo e pela pregação (cf. 1Cor 4,15; 1Pd 5,25). De coração feitos modelos para o rebanho (cf. 1Pd 5,3), presidam e sirvam de tal modo a comunidade local, que esta dignamente possa ser chamada com aquele nome pelo qual só e todo o povo de Deus é distinguido, a saber: Igreja de Deus (cf. 1Cor 1,2; 2Cor 1,1 e passim)".

Toda teologia da ordem é relida em chave missionária, desenvolvendo a identidade sacramental através do triplex munus. Existe vínculo ontológico entre o presbítero e Cristo, através do vinculo entre o presbítero e o bispo. Trata-se de um vinculo criado pela ordenação e não pela jurisdição. Por isto os três munera são reconduzidos à ordem sagrada. O culto e a celebração dos sacramentos, a pregação e a guia pastoral realizam as três partes da essência do sacerdócio. O triplex múnus por sua vez indica o conteúdo missionário do presbítero; assim no Decreto Presbiterorum Ordinis (PO) tudo que foi dito a respeito do episcopado na forma da participação do presbiterado.

$L G 28$ tinha afirmado: "Os presbíteros [...] em virtude do sacramento da ordem (vi sacramenti Ordinis), feitos à imagem de Cristo, sumo eterno sacerdote, são consagrados para pregar o Evangelho, apascentar os fiéis e celebrar o 
culto divino, como verdadeiros sacerdotes do Novo Testamento". Não se trata de três tarefas justapostas, mas de três aspectos do ministério apresentados nos números 4,5 e 6 da $P O$ sempre em relação entre eles.

Outro passo realizado pelo concílio é a referência $(P O 8)$ à "Fraternidade entre Presbíteros", porque formam um "só presbitério" e assim "desempenham um único ministério sacerdotal em favor dos homens".

\section{Motivações e desdobramentos}

\subsection{Motivações Cristológicas}

Depois de 50 anos da conclusão do Concílio Vaticano II, estamos no grau de afirmar que um dos pontos nos quais mais se mostrou a dialética continuidade-ruptura na vida da Igreja foi o debate sobre a identidade do sacerdote. Neste ponto foi particularmente desenvolvida a hermenêutica da descontinuidade, ${ }^{1}$ chegando-se a usar somente a terminologia de presbíteros, abandonando-se aquela de sacerdotes; insistindo-se, muitas vezes unilateralmente, sobre o fundamento eclesiológico ou puramente funcional do ministério ordenado.

Diante destas teses, João Paulo II, recolhendo o ensinamento do sínodo de 1990 sobre a "Formação sacerdotal hoje", tinha dito na exortação apostólica Pastores Dabo Vobis:

Não se pode então definir a natureza e a missão do sacerdócio ministerial, se não nesta múltipla e rica rede de relações; que brotam da Santíssima Trindade, que se prolongam na comunhão da Igreja, como sinal e instrumento, em Cristo, da união com Deus e da unidade do todo gênero humano. Neste contexto a eclesiologia de comunhão torna-se decisiva para colher a identidade do presbítero, sua original dignidade, sua vocação e missão no povo de Deus e no mundo. A referência à Igreja, é, portanto, necessária é até prioritária na definição da identidade do presbítero. Enquanto mistério, de fato, a Igreja é essencialmente relativa a Jesus Cristo: dele, de fato, é a plenitude, o corpo, a esposa. É o "sinal" e o "memorial" vivo da sua presença permanente e ação entre nós e para nós. O presbítero encontra a verdade plena na sua identidade em ser uma derivação, uma participação específica e uma continuação de Cristo

${ }^{1}$ BENTO XVI. Discurso aos membros da Cúria e da Prelatura Romana para a apresentação dos votos natalícios. 22 de dezembro de 2005 . 
mesmo, sumo e único sacerdote da nova e eterna Aliança: Ele é a imagem viva e transparente de Cristo sacerdote. O sacerdócio de Cristo, expressão da sua absoluta "novidade" na história da salvação constitui a fonte única e paradigma insubstituível do sacerdócio do cristão e, especialmente, do presbítero. A referência a Cristo é então a chave absolutamente necessária para a compreensão da realidade sacerdotal. ${ }^{2}$

O Papa Bento XVI, referindo-se à crise de identidade do sacerdote, assim se expressou no famoso discurso à Cúria Romana para os votos natalícios no seu primeiro ano de pontificado. O Papa fez uma leitura atenta do Vaticano II e do clima pós-conciliar, falando diretamente da "hermenêutica da descontinuidade e da ruptura e de uma hermenêutica para reforma".

$\mathrm{Na}$ "perspectiva da reforma", o ministério ordenado é descrito com a manifestação da imagem bíblica do bom Pastor que dá a vida para o seu rebanho, como participação na missão de Cristo e como presença sacramental de Cristo cabeça da Igreja. Do sacerdócio de Cristo participam todos os fiéis, mas é diversa a situação dos apóstolos daquela dos outros discípulos de Jesus. Os Doze foram escolhidos para pregar o evangelho a todas as gentes, para celebrar os santos mistérios, para presidir a Eucaristia e para guiar as comunidades. O ministério apostólico se prolonga no ministério pós-apostólico dos sucessores dos apóstolos e de seus diretos colaboradores. O próprio Cristo continua a sua missão sacerdotal de cabeça do seu povo por meio de ministros que, através dos apóstolos e de seus sucessores, Ele mesmo escolhe. O ministério ordenado se religa assim à unção e missão próprias de Cristo e d'Ele participada pelos apóstolos. Pelos seus sucessores e seus colaboradores. ${ }^{3}$

Recebido o sacramento, o sacerdote é configurado a Cristo cabeça da Igreja e recebe nova capacidade de agir. Uma vez ordenados, os presbíteros são homens novos, inseridos ontologicamente no mistério de Cristo e são chamados a uma "apostolica vivendi forma" que Bento XVI recordou no seu discurso à Congregação para o Clero.

Pela imposição das mãos do bispo e a oração consacratória da Igreja, os candidatos se tornam homens novos, tornam-se "presbíteros". Nesta luz

${ }^{2}$ JOÃO PAULO II. Exortação pós-sinodal Pastores Dabo Vobis.

${ }^{3}$ BENTO XVI. Discurso aos membros da Cúria e da Prelatura Romana para a apresentação dos votos natalícios. 22 de dezembro de 2005. 
aparece claro como os tria munera são primeiramente um dom e só consequentemente um oficio; primeiramente uma participação em uma vida, e por isso uma potestas. Certamente, a grande tradição eclesial justamente desvinculou a eficácia sacramental da situação concreta existencial do sacerdote enquanto indivíduo; assim as legítimas expectativas dos fiéis são adequadamente salvaguardadas. Mas, esta justa precisão doutrinal não tira a necessária e indispensável tensão para a perfeição moral, que deve habitar em todo coração autenticamente sacerdotal. ${ }^{4}$

O tema da vida do padre e da sua retidão moral nos interpela muito, sobretudo depois de um período crítico de acusações e de descobertas desconcertantes acerca da vida dupla dos presbíteros. Indo às raízes do mal estar do presbítero, o Papa Bergoglio disse na homilia de 12 de janeiro de 2014:

Nós sacerdotes temos tantos limites: somos pecadores, todos. Mas se formos a Jesus Cristo, se procuramos o Senhor na oração - oração de intercessão, oração de adoração - somos bons sacerdotes, se bem que sejamos pecadores. Mas se nos afastamos de Jesus Cristo, devemos compensar isto com outras atitudes mudanas. Assim, todas estas figuras, também o padre-atarefado, padre-empreendedor. Mas o padre que adora Jesus Cristo, padre que fala com Jesus Cristo, padre que procura Jesus Cristo e que se deixa encontrar por Jesus Cristo: este é o centro da nossa vida. Se não existe isso, perdemos tudo. E que coisa daremos às pessoas?

Na passagem precedente, o Papa Francisco tinha criticado os padres tomados pela vaidade, definindo-os padres-borboletas. "Aquilo que nos salva da mundanidade e da idolatria, que nos faz ungidos, aquilo que nos conserva na unção é o relacionamento com Jesus Cristo". Então o primado cristológico está na união sacramental naquele que é fonte e cume do próprio sacerdote: Cristo Senhor.

\subsection{Motivações pneumatológicas}

Todo presbítero recebe o Espírito do Senhor na sua ordenação que o torna participante do único sacerdote de Cristo, na sua missão e do seu serviço aos homens. ${ }^{5}$ Os presbíteros "consagrados pela unção do Espírito Santo"

\footnotetext{
${ }^{4}$ Ibidem.

${ }^{5}$ Cf. CONCÍLIO VATICANO II. Decreto Presbyterorum Ordinis, n. 2c.
} 
são assinalados por um caráter especial que os faz "configurados com Cristo Sacerdote", 6 e estes "existem e agem para o anúncio do Evangelho ao mundo e para a edificação da Igreja em nome e na pessoa de Cristo cabeça e pastor".? Os presbíteros são assim "consagrados pela unção do Espírito e enviados por Cristo" , 8 e neles os bispos têm seus "necessários cooperadores e conselheiros no ministério". ${ }^{9}$ Qualquer ministro ordenado pode tornar próprio o texto do profeta Isaías que Jesus aplicou a si mesmo na sinagoga de Nazaré: “O Espírito do Senhor está sobre mim; (...) mandou-me para anunciar aos pobres uma alegre mensagem" (Lc 4,18).

Daqui nasce no sacerdote a exigência de uma sintonia de seu ser e sua ação. Neste sentido, disse o Papa João Paulo II:

O Espírito do Senhor consagrou Cristo e o mandou a anunciar o Evangelho (cf. Lc 4,18). A missão não é elemento exterior e justaposto à consagração, mas constitui a destinação intrínseca e vital: a consagração é para a missão. Assim, não só a consagração, mas também a missão estão sobre o sinal do Espírito, sobre seu influxo santificador. Assim aconteceu com Jesus. Assim aconteceu com os apóstolos e seus sucessores. Assim com toda a Igreja e nela os presbíteros: todos recebem o Espírito como dom e apelo de santificação no e através do cumprimento da missão. ${ }^{10}$

O Espírito Santo é aquele que torna capazes os presbíteros de uma vida nova, em vista da missão. A efusão do Espírito torna-se fonte de graça interior e transforma o ser do ministro ordenado e o torna capaz de comunicar os efeitos salvíficos da única mediação de Cristo.

De outra parte, o Espírito "sopra aonde quer" (Jo 3,8), e também está presente no coração do homem, dispondo-o a acolher a revelação e preparando-o ao encontro com Cristo. Todo sacerdote deve estar sempre consciente disto: a missão não é sua, ele não está só, mas é o Espírito que guia e o precede no coração de todo homem.

Na missa do crisma em 28 de março de 2013, o Papa retoma um aspecto posterior da vida do padre:

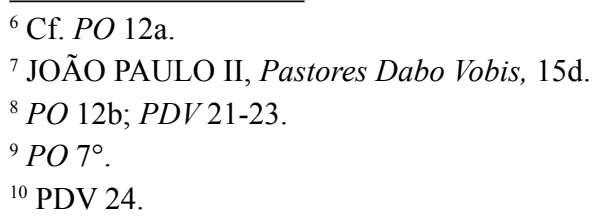


Precisa sair e experimentar nossa unção, seu poder e sua eficácia redentora: nas "periferias" onde existe sofrimento, existe sangue derramado, existe cegueira que deseja ver, existem prisioneiros de tantos maus patrões. Não é precisamente nas auto-experiências ou nas introspecções reiteradas que encontramos o Senhor: os cursos de autoajuda da vida podem ser úteis, mas viver passando de um curso ao outro, de método a método, observou o Pontífice, "leva a tornarmo-nos pelagianos, a minimizar o poder da graça" que explicou - "se ativa e cresce na medida em que, com fé, saímos a dar a nós mesmos e a dar o Evangelho aos outros, a dar pouca unção que temos àqueles que não têm nada de nada. O sacerdote que sai pouco de si, que unge pouco - não digo "nada" para que nossa gente se encha de unção, graças a Deus - perde o melhor do nosso povo, aquilo que é capaz de ativar a parte mais profunda do nosso coração presbiteral".

"Quem não sai de si - disse ainda o Papa Bergoglio - ao invés de ser mediador, torna-se pouco a pouco intermediário, um gestor. Todos nós conhecemos a diferença: o intermediário e o gestor "têm já sua paga" e assim como não põem em jogo a própria pele e o próprio coração, não recebem um agradecimento afetuoso, que nasce do coração. Daqui deriva precisamente a insatisfação de alguns, que acabam por ser tristes transformados em uma série de colecionadores de antiguidades ou mesmo novidades, ao invés de ser pastores com o "cheiro das ovelhas", pastores em meio ao próprio rebanho, e pescadores de homens".

São palavras das quais emerge a identidade de um pastor que sai à procura da ovelha perdida nas periferias geográficas e existenciais do nosso mundo. Encontrando-a, diz-lhe antes de tudo que é amada por Deus e é perdoada por Ele só se reconhece necessitada da sua misericórdia. Mas diz também que sua missão "carismática" está em estreita sintonia, em princípio, do Espírito, que é imprevisível e que move e renova sempre a Igreja.

\subsection{Motivações eclesiológicas}

O sacramento da Ordem produz nos ordenados um novo modo de ser e de operar na Igreja, não fora ou acima da comunidade eclesial, mas no interior dela, com tarefa específica recebida na ordenação.

A base da doutrina do Vaticano II sobre o sacerdócio é constituída pela concepção da Igreja e como "sacramento ou sinal e instrumento da íntima união com Deus e da unidade de todo o gênero humano". ${ }^{11}$ Que todo cristão

\footnotetext{
${ }^{11}$ CONCÍLIO VATICANO II. Constituição dogmática Lumen Gentium 1; Cf. $L G$ 48; et alli.
} 
é sinal de Cristo, o sacerdote é sinal de Cristo enquanto "Cabeça e Bom Pastor". ${ }^{12}$ Desta identificação sacramental nascem as funções de ministro da Palavra, dos sacramentos e da atividade salvifíca e pastoral de Cristo. ${ }^{13} \mathrm{O}$ sacerdote é "instrumento vivo de Cristo Sacerdote". ${ }^{14}$

No pós-concilio é deflagrada a crise sacerdotal que Paulo VI enfrentou com clareza e coragem numa tempestade de críticas, seguida pela sua encíclica Sacerdotalis Coelibatus de 1976. João Paulo II, continuando o magistério do Concílio e de Paulo VI, indica o Sínodo de 1990 e na exortação Pastores Dabo Vobis retoma e confirma a concepção conciliar do sacerdote como transparência e sinal do Bom Pastor no mundo de hoje.

Nasce da participação da unção e missão de Cristo uma espiritualidade sacerdotal que edifica a Igreja, seguindo uma radicalidade os conselhos evangélicos da obediência, da castidade e da pobreza. Na Igreja comunhão, (categoria muito desenvolvida depois do Sínodo de 1985), é decisivo o espírito e a prática da fraternidade sacerdotal como expressão da caridade pastoral.

Alma e forma da formação permanente do sacerdote é a caridade pastoral: O Espírito Santo, quem infunde a caridade pastoral, introduz e acompanha o sacerdote a conhecer sempre mais o mistério de Cristo que é insondável na sua riqueza e, indiretamente, a conhecer o mistério do sacerdócio cristão. A mesma caridade pastoral motiva o sacerdote a conhecer sempre mais as perspectivas, necessidades, problemas, as sensibilidades dos destinatários do seu ministério: destinatários acolhidos, situações concretas pessoais, familiares, sociais. ${ }^{15}$

Desta identificação com Cristo Bom Pastor e as necessidades concretas das pessoas, toma forma a participação na missão salvífica da Igreja.

Na Igreja "missão" a formação permanente do sacerdote entra não só como condição necessária, mas também como meio indispensável para retomar constantemente com ardor o senso da missão e garantir-lhe uma realização fiel e generosa. ${ }^{16}$

Neste contexto eclesiológico e necessário, a referência a Maria, que é modelo da comunhão eclesial e da missão sacerdotal. A Igreja, como Maria, recebe a Palavra, o Verbo, e torna-se mãe. Analogamente, o sacerdote dá ao mundo o Filho de Deus por meio do seu ministério. Mas é Maria que tem uma

\footnotetext{
${ }^{12} \mathrm{PO} 2$.

${ }^{13}$ Cf. $P O 4-6$.

${ }^{14} \mathrm{PO} 12$.

${ }^{15}$ PDV 70.

${ }^{16}$ PDV 75.
} 
função materna na vida do sacerdote, porque, olhando-a, aprende a acolhida da Palavra, a perseverança do seu sim e a participação na oferta da cruz.

A dimensão mariana do presbítero não é apenas um importante componente afetivo e devocional, mas é um elemento constitutivo do seu ser e operar. ${ }^{17}$ É referência substancial no viver o coração da consagração em missão do sacerdote como sinal sacramental do Bom Pastor.

Enfim, em contexto eclesiológico, notamos um importante discurso feito pelo Papa Bento XVI na última audiência plenária da Congregação para o Clero, onde ele colocava em evidência as dimensões das missões do presbítero, identificando a sua origem no mistério de Deus e da Igreja. O Papa falava da dimensão eclesial, comunal, hierárquica e doutrinal, que são absolutamente indispensáveis a toda missão autêntica; e acrescentava:

Os quatro aspectos mencionados devem ser sempre reconhecidos como intimamente relacionados: a missão é "eclesial" porque ninguém anuncia ou leva a si mesmo, mas na e através da própria humanidade todo sacerdote deve ser bem consciente de levar Outro, Deus mesmo, ao mundo. Só Deus é a riqueza que, em definitivo, os homens desejam encontrar em um sacerdote. A missão é "comunal", porque desenvolve em unidade e comunhão que só secundariamente tem também aspectos relevantes de visibilidade social. Estes, de outra parte, derivam essencialmente daquela intimidade divina da qual o sacerdote é chamado a ser expert, para poder conduzir, com humildade e confiança, as almas a ele confiadas para o mesmo encontro com o Senhor. Enfim as dimensões "hierárquica" e "doutrinal" sugerem retomar a importância da disciplina (o termo se liga com “discípulo") eclesiástica e da formação doutrinal, e não é só teológica, inicial e permanente. ${ }^{18}$

Recordamos também como a $P O$ fala da íntima e profunda comunhão que incorre entre presbítero/presbitério e bispo. Este dado eclesiológico é fundamental; de fato, no número 7 se afirma que os bispos terão de ser:

${ }^{17}$ Cf. CONGREGAÇÃO PARA O CLERO. O presbitero pastor e guia da Comunidade Paroquial: "Em Maria, mãe do Sumo e Eterno Sacerdote, sacerdote toma consciência de ser com Ela, "instrumento de comunicação salvífica entre Deus e os homens", ainda que modo diferente: a Santa Virgem mediante a encarnação, o sacerdote mediante os poderes da Ordem", 8.

${ }^{18}$ BENTO XVI. Discurso aos participantes da plenária da Congregação para o Clero. 19 de março de 2009. 
Como irmãos e amigos, tomem com o coração e com todas as forças o bem-estar deles, material e especialmente espiritual. Aos bispos de fato incumbe, sobretudo, o grave empenho da santidade dos seus sacerdotes; devem, portanto, tomar o máximo cuidado pela contínua formação do próprio presbitério. Ouçam voluntariamente seu parecer, antes tomem para si mesmos a iniciativa de consultá-los e dialogar com eles sobre quanto concerne às necessidades do seu trabalho pastoral para o bem da diocese. ${ }^{19}$

Tudo isto não deixa de nos provocar, enquanto bispos, na visão comunal que o Concílio solicita e que está em perfeita linha com o estilo sinodal que o Papa Francisco está testemunhando. Então "Não" aos absolutismos indevidos ou solidões episcopais; "Sim" a um caminho de amizade fraterna em Cristo entre o bispo e presbitério na lógica do respeito das funções e na corresponsabilidade que exprimem e realizam o ser em uma única família.

\section{Desafio da Missão}

\subsection{A dimensão missionária do presbítero}

Pelos documentos analisados e pelas reflexões até aqui desenvolvidas, demonstrou-se a prevalência da perspectiva trinitária e cristológica para fundamentar o ministério ordenado, sem descuidar da dimensão pneumatológica e eclesial. Destes fundamentos emerge a linha evangélica do Cristo consagrado e enviado ao mundo pelo Pai (Jo 10,36), para fundamentar a dimensão missionária do presbítero.

A partir da consciência de Jesus em ser o enviado do Pai que, por sua vez, envia os apóstolos (Jo 13,20; 17,18; 20,21) se desenvolve uma "cristologia da missão" que especifica a natureza missionária do presbítero na Igreja. O ser do presbítero é caracterizado desde o início pela "consagração-missão" em uma representação sacramental e vicária do próprio Cristo. A missão assim não é um apêndice, mas um elemento estruturante do ser do presbítero que a Pastores Dabo Vobis define como "Cabeça e Pastor da Igreja". ${ }^{20}$

Esta missão missionária ou extrínseca da Igreja é uma das pérolas que este Papado está nos oferecendo como critério teológico-pastoral. Na exortação Evangelii Gaudium n. 49 o Papa Francisco afirma:

\footnotetext{
${ }^{19}$ PO 7: EV 1/1264.

${ }^{20}$ PDV 15. O texto completo diz: "Os presbíteros existem e agem para o anúncio do Evangelho ao mundo e para edificação da Igreja em nome e na pessoa de Cristo Cabeça e Pastor”.
} 
Prefiro uma Igreja acidentada, ferida e suja por ter saído pelas estradas, mais do que uma Igreja enferma pelo fechamento e a comodidade de agarrar-se às próprias seguranças. Não quero uma Igreja preocupada em ser o centro e que acaba fechada em um emaranhado de obsessões e procedimentos. Se alguma coisa deve santamente inquietar e preocupar nossa consciência que tanto de nossos irmãos, sem a força, a luz e a consolação da amizade com Jesus Cristo, sem uma comunidade de fé que os acolha, sem horizonte de sentido e de vida.

Estas palavras inquietantes nos movem para uma ministerialidade atenta às relações, preocupada de deixar-se de interpelar pelo olhar do irmão, de quem encontro pela estrada, sempre prontos a acolher e acompanhar como bons samaritanos. É esta a antropologia cristológica do ministério presbiteral que o Papa está nos ensinando com a vida.

A mesma Exortação Apostólica de João Paulo II acrescenta novo aspecto: "enquanto representa Cristo cabeça, pastor esposo da Igreja, o sacerdote se coloca um só na Igreja, mas também diante da Igreja". ${ }^{21}$

Assim se indica o fato que, se por um lado o sacerdote é um fiel que faz parte da comunidade como homem de comunhão que exerce o seu ministério na força do Espírito de Jesus ressuscitado como animador da comunidade, de outro é imagem viva de Cristo esposo da Igreja diante da qual também o sacerdote é o esposo.

A motivação teológica oferecida pela Pastores Dabo Vobis põe em evidencia o primado absoluto da graça da qual o sacerdote é sinal.

Assim, por sua mesma natureza e missão sacramental, o sacerdote aparece, na estrutura da Igreja, como sinal da prioridade absoluta e da gratuidade da graça, que é dada à Igreja pelo Cristo ressuscitado. Por meio do sacerdócio ministerial a Igreja toma consciência, na fé, de não existir por si mesma, mas pela graça de Cristo no Espírito Santo. Os apóstolos e seus sucessores, enquanto detentores de uma autoridade que lhes advém do Cristo Cabeça e Pastor são postos, com seu ministério, diante da Igreja como prolongamento visível e sinal sacramental do Cristo em seu próprio estar diante da Igreja e do mundo, como origem permanente da salvação, "Ele que é o salvador do seu corpo". 22

Bento XVI, valorizando o magistério anterior, retomou sinteticamente a origem da dimensão missionária do presbítero em ser sinal de Cristo cabeça, e isto comporta um modo diferente de viver que é o sinal do anúncio missionário.

${ }^{21}$ PDV 22.

${ }^{22}$ Ibidem, 16. 
A dimensão missionária do presbítero nasce da sua configuração sacramental ao Cristo cabeça: esta traz consigo como consequência uma adesão cordial e total, aquela que a tradição eclesial individuou como a apostólica forma de viver. Esta consiste na participação de uma "vida nova" espiritualmente compreendida, aquele "novo estilo de vida" que foi inaugurada pelo Senhor Jesus e se tornou própria dos apóstolos. ${ }^{23}$

A missão é o testemunho da vida mudada pelo encontro com o Senhor e pela consagração sacerdotal. A apostolica vivendi forma nos remete ao estilo de vida dos apóstolos que percorreram toda a terra então conhecida para anunciar Cristo e construir a Igreja. $\mathrm{O}$ apóstolo que percorre as estradas dos povos encontra as pessoas, anuncia a Palavra, celebra os santos mistérios e atrai os corações com a força do Espírito e pelo fascínio da sua vida. Certamente também o apóstolo sente a desproporção entre aquilo que traz e suas capacidades pessoais, mas sua vida é dominada pela presença de Cristo e pela tarefa por Ele recebida. Por isso continua Bento XVI:

Pela imposição das mãos do bispo e oração consacratória da Igreja, os candidatos tornam-se homens novos, tornam-se "presbíteros". Nesta luz aparece claro como os três múnus são primeiramente um dom e só consequentemente um ofício, primeiramente uma participação a uma vida, e, portanto, a uma potestas. Certamente, a grande tradição eclesial já justamente desvinculou a eficácia sacramental da situação concreta existencial do sacerdote em particular, e assim as legitimas expectativas dos fiéis são adequadamente salvaguardadas. Mas esta justa precisão doutrinal nada exclui da necessária, também indispensável, tensão para perfeição moral, que deve habitar em todo coração autenticamente sacerdotal. ${ }^{24}$

O anúncio nasce desta experiência nova que o exercício dos Tria munera produz porque antes de ser "um ofício" e "uma potestas" é "um dom" e "participação a uma vida". O Papa afirma o ano sacerdotal, por ocasião do $150^{\circ}$ aniversário de morte do São Cura D’Ars, é indicado: “para favorecer esta tensão dos sacerdotes para a perfeição espiritual da qual, sobretudo, depende a eficácia do seu ministério". ${ }^{25}$

${ }^{23}$ BENTO XVI. Discurso aos participantes da plenária da Congregação para o Clero. 16 de março de 2009.

${ }^{24}$ Ibidem.

${ }^{25}$ Ibidem. 


\title{
3.2. Comunicar existencialmente a existência da consagração
}

O Papa Bento XVI na Missa da quinta-feira Santa de 2009 indicava a linha da espiritualidade missionária sacerdotal:

\begin{abstract}
"Consagrados na verdade: é esta verdadeira oração de consagração para os apóstolos. O Senhor pede que Deus mesmo atraia para si, dentro da sua santidade. Pede que Ele Deus os subtraia a si próprios e os tome como sua propriedade, a fim de que, a partir dele, eles possam desenvolver o serviço sacerdotal para o mundo. (...) Cristo pede para os discípulos a verdadeira santificação, que transforma o seu ser, eles mesmos; que não permaneça em uma forma ritual, mas que seja um verdadeiro tornar-se propriedade do próprio Deus. Podemos também dizer: Cristo pediu para nós o Sacramento que nos toca na profundidade de nosso ser. Mas também rezou a fim de que esta transformação, dia a dia, em nós se traduza em vida; afim de que em nosso cotidiano e nossa vida concreta de todo dia sejamos verdadeiramente penetrados pela luz de Deus". ${ }^{26}$
\end{abstract}

Aquilo que ontologicamente nos é dado pela ordenação, segundo as palavras do Papa, é orientado a traduzir-se dia a dia em vida para que a novidade do encontro com Cristo seja visível e constitua a forma histórica da missão. A espiritualidade não é outra coisa que a vida no Espírito, documentada na oferta de si e na missão.

O novo ser em Cristo e particularmente ser sinal de Cristo cabeça da Igreja é destinado à fecundidade a testemunhar como é capaz de transformar a vida. A nova criatura edifica na sociedade um povo diverso e é chamada a entrar em todo mundo. A realidade da Igreja se afirma não como ideologia (teoria e práxis), mas como capacidade de transformar a vida. $\mathrm{O}$ anúncio nasce de um coração no encontro com Cristo haja o início do seu cumprimento sem Cristo andaria em frangalhos.

A missão é vibrar por uma razão inquieta que não se satisfaz com as respostas que correm sobre a superfície da realidade, mas que arrisca a aventura do Mistério. Como já dizia Platão "Kálos gar ho Kindynos" (Fédon, 114d), O risco é belo. A missão ocorre quando também a afetividade se lança para o seu objeto adequado: o abraço do bem infinito e concreto. A experiência de Cristo como completude do coração, razão, desejo, afetividade, é

${ }^{26}$ BENTO XVI. Homilia na Santa Missa do Crisma. 09 de Abril de 2009. 
o principio existencial da missão. Disse o Senhor: "quem me segue terá a vida eterna e o cêntuplo aqui" (cf. Mt 19,29; Mc 10,29-30; Lc 18,30). Tendo deixado tudo e seguido o Senhor, como Pedro e os apóstolos, faz-se a experiência daquilo que preenche a vida e anuncia-a a todos. A missão é concluída na glória de Cristo na verdadeira felicidade dos homens.

Escreve São Paulo aos Coríntios: "O amor de Cristo nos impele ao pensamento que, se um morreu por todos, morreu para que todos não vivam mais para si mesmo, mas para aquele morreu e ressuscitou por todos" (2 Cor 5, 14-15). A missão é a paixão para que todos vivam por Aquele que morreu e ressuscitou.

A missão é este viver para, que implica uma autoconsciência nova e um novo princípio de ação no qual não existe mais o eu, mas o Tu. Como dizia Jesus "Eu fui enviado pelo Pai". Paulo indica a nova fonte de ação: "Não sou eu quem vivo; mas é Cristo quem vive em mim" (Gal 2,20). Obediência total a outro como conteúdo da nova autoconsciência e dinâmica missionária são a mesma coisa. Aquilo que ocorre na Trindade, aquilo que ocorre na pessoa de Cristo, ocorre, com as devidas proporções, mas de modo real na vida do missionário.

Em contexto no qual prevalece a "globalização da indiferença", como disse o Papa (Evangelii Gaudim 54) emerge nosso empenho missionário de padres atraídos pelo modelo trinitário, por aquela extroversão e espoliação que Cristo Senhor nos ensinou. Portanto, não "à acédia egoística e paralisante" (Cf. ibidem 81) que leva muitos sacerdotes a retalhar espaços de liberdade, de autonomia que os leva à indiferença estendida em relação aos outros. Isto frequentemente encobre afetividade não pascal, sonhos de sucesso cultivados com vaidade, domínio da história e da vida concentrando-se mais sobre projeções e sobre a estrutura formal da pastoral, sobre a organização do que sobre relações fecundas (cf. Ibidem $82-83$ ).

\subsection{Do ser à missão: um itinerário educativo}

O ministério ordenado, através do anúncio da Palavra, o Sacramento e o cuidado da comunidade, gera o sujeito da missão, o povo de Deus que anuncia até os confins do mundo as maravilhas do Senhor.

A passagem do ser à missão não é automática; é necessário que a potencialidade se desenvolva; que a semente amadureça na dinâmica concreta da vida e não apenas em iniciativas ocasionais e em atividades de especialistas.

Um grande educador, Luigi Giussani, dizia que a missão não é o fim, mas 
o método da educação. Já em um texto dos anos 60 dizia: "O ideal seria poder fazer nascer na mentalidade dos estudantes a necessidade de uma perspectiva nova de estudar, na escolha da profissão, na concepção da estrada da vida: uma perspectiva que exceda o limite de uma conveniência, de uma carreira, e ao invés atravesse fronteiras apaixonadamente na concepção de ser útil ao mundo e à história". ${ }^{27}$ A missão não chega ao final, depois de um longo processo de maduração, mas ela mesma é o elemento essencial da personalidade cristã.

Esta passagem advém com a força da presença do mestre; e não simplesmente por aquilo que este diz ou pelas instruções que dá, mas como ele vive e como trata a realidade. Os apóstolos aprenderam a missão porque viram como Jesus a vivia e obedeceram ao seu mandamento. À sua volta, vivendo o estilo de vida de Jesus, se tornaram mestres para gerações sucessivas.

$\mathrm{Na}$ vida do Senhor houve um momento, no início do seu ministério público, quando a sua humanidade, já unida à pessoa do Verbo, recebeu no batismo uma nova unção em vista do seu ofício messiânico. Mediante a unção do Espírito se explica na história aquele empenho que existe na Trindade, a função de ser nexo de amor entre o Pai e Filho. Tudo isto para dizer que o magistério externo de Jesus, os apóstolos, da Igreja é acompanhado pelo magistério interno do Espírito. O mestre exterior se une ao mestre interior que, particularmente no momento da perseguição, também na maior solidão, sugere palavras adequadas (cf. Mt 10,19-20). Santo Agostinho fala do Espírito como "mestre interior". 28

O testemunho interior deve, pois, sempre conjugar-se com o testemunho exterior, com os dons e os carismas que o mesmo Espírito suscita e em entre os quais está o dom da função magisterial da Igreja.

A efusão do Espírito com seu magistério interior e exterior sempre acompanhou a história da Igreja particularmente em épocas decisivas e sempre suscitou novo ímpeto missionário. Recordamos só alguns momentos como expansão da

${ }^{27}$ GIUSSANI, Luigi. Gioventù Studentesca. Riflessioni sopra un'esperienza. Oggi in: Il cammino al vero è un'esperienza, Rizzoli, Milano, 2006, p. 75. Em port.: Gioventù Studentesca. Reflexões sobre uma experiência. Hoje in: O caminho para a verdade é uma experiência. Companhia Ilimitada, São Paulo, 2006, p. 93.

${ }^{28}$ AGOSTINHO. Sobre a primeira carta de João, 3,13; 4,1 (PL 35,2004 s.). "não tem necessidade que ninguém vos instrua?" Talvez o cristão em particular saiba já tudo por conta sua e que não tenha necessidade de ler, de se instruir, de escutar ninguém? Mas se fosse assim, com que objetivo o apóstolo teria escrito esta sua carta? A verdade é que há necessidade de escutar os mestres externos e os pregadores externos, mas só compreenderá e aproveitará daquilo que eles dizem aquele ao qual fala no íntimo o Espírito Santo. Isto explica por que muitos escutam a mesma pregação e o mesmo ensinamento, porém não todos compreendem do mesmo modo. 
Igreja no mundo helênico e romano; as missões ligadas aos descobrimentos do inicio da época moderna; a difusão missionária da Igreja na segunda metade de 1800 e em 1900 por obra das ordens e congregações religiosas.

A missão é suscitada pelo Espírito que se serve dos carismas para despertar em toda a Igreja a paixão missionária. A missão antes de ser o partir para terras distantes é a transformação da vida cotidiana que se torna desejo ardente de comunicar o princípio da vida nova. A passagem do ser para a função advém por um encontro vivo e pela presença de um mestre que ajuda a julgar com o olhar de Cristo os interesses e as formas da vida cotidiana.

Antes de cursos sobre missões, de grupo de estudo e grupo de trabalho, trata-se de um encontro e de um fascínio. Muito oportunamente em toda América Latina e no Caribe, sobretudo depois da Conferência de Aparecida se insiste sobre a "missão permanente" e (no capítulo VI do Documento) sobre a Formação dos Discípulos missionários como um fato global e não apenas como resposta preocupada pelo avanço das seitas. Quanto mais se é consciente da vida como missão, mas se constrói o Reino de Deus e se é responsável pela missão da Igreja.

Nesta perspectiva o ministério ordenado tem um peso todo particular porque sustenta o povo de Deus no seu ser e no seu empenho por meio do tríplice múnus. Assim do coração da Trindade se desenvolve uma dinâmica irresistível que tem seu ponto culminante na cruz e ressurreição do Senhor e que se dilata no mundo com a força do Espírito e mediante a obra educativa da Igreja.

\section{Conclusão}

Um santo bispo da minha região, Dom Tonino Bello, costumava dizer que frequentemente na visão "presbiteral" aparecem mais os direitos de estola que os deveres do gremial, retomando João 13. É belo pensar a missão do presbítero segundo o Concílio em chave diaconal, onde o serviço se torna profecia do Cristo Mestre que se doa totalmente, pondo-se a serviço do outro. Portanto, as palavras do Papa Francisco na Evangelii Gaudium n. 169 podem ser uma síntese e uma provocação importante.

A Igreja deve iniciar seus membros - sacerdotes, religiosos, leigos - nesta "arte do acompanhamento", para que todos aprendam sempre a tirar as sandálias diante da terra sagrada do outro (Cf. Ex 3,5). Devemos dar ao nosso caminho o ritmo salutar da proximidade, com um olhar respeitoso e pleno de compaixão, mas ao mesmo tempo sãos e livres e encorajados a amadurecer na vida cristã. 


\section{Referências bibliográficas}

AGOSTINHO. Sobre a primeira carta de João, 3,13; 4,1 (PL 35,2004 s.).

BENTO XVI. Discurso aos membros da Cúria e da Prelatura Romana para a apresentação dos votos natalícios. 22 de dezembro de 2005.

BENTO XVI. Discurso aos participantes da plenária da Congregação para $o$ Clero. 16 de março de 2009.

BENTO XVI. Discurso aos participantes da plenária da Congregação para o Clero. 19 de março de 2009

BENTO XVI. Homilia na Santa Missa do Crisma. 09 de Abril de 2009.

CONCÍLIO VATICANO II. Constituição dogmática Lumen Gentium. In: Enchiridion Vaticanum.

CONCÍLIO VATICANO II. Decreto Presbyterorum Ordinis. In: Enchiridion Vaticanum.

CONGREGAÇÃO PARA O CLERO. O presbitero pastor e guia da Comunidade Paroquial.

GIUSSANI, Luigi. Gioventù Studentesca. Riflessioni sopra un'esperienza. Oggi in: Il cammino al vero è un'esperienza, Rizzoli, Milano, 2006, p. 75. Em port.: Gioventù Studentesca. Reflexões sobre uma experiência. Hoje in: $O$ caminho para a verdade é uma experiência. Companhia Ilimitada, São Paulo, 2006, p. 93.

JOÃO PAULO II. Exortação pós-sinodal Pastores Dabo Vobis.

Dom Filippo Santoro

Doutor em Teologia pela Pontificia Università Gregoriana

Consultor do Pontifício Conselho para os Leigos

Taranto / Itália

e-mail: segretariavescovo@taranto.chiesacatolica.it

Recebido em: 17/10/14

Aprovado em: 20/10/14 